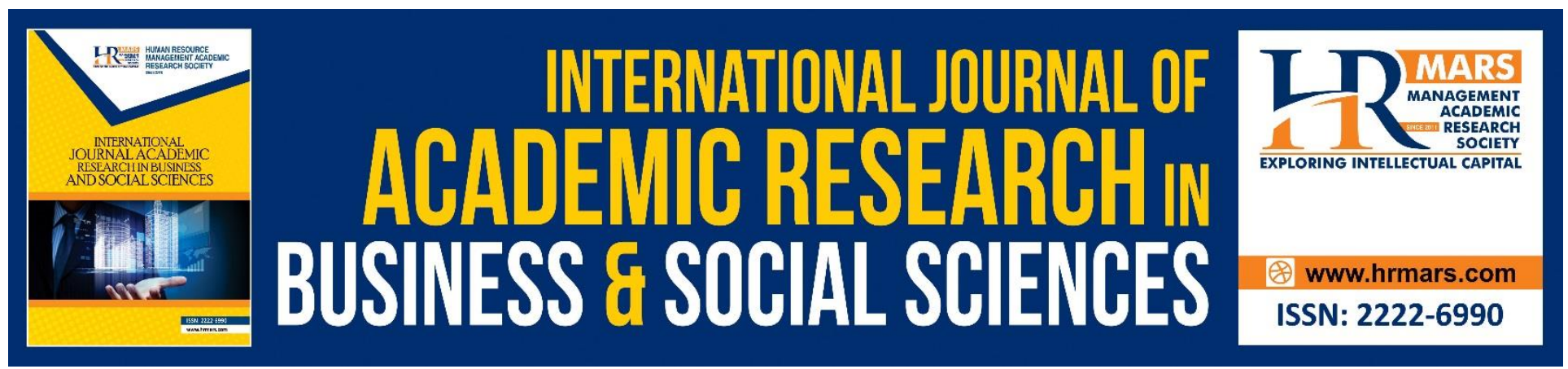

\title{
Implementation of Relationship Marketing in Takaful through Wakalah Business Model
}

\author{
Murni Yusoff
}

To Link this Article: http://dx.doi.org/10.6007/IJARBSS/v8-i11/4993

DOI: $10.6007 /$ IJARBSS/v8-i11/4993

Received: 29 Oct 2018, Revised: 17 Nov 2018, Accepted: 11 Dec 2018

Published Online: 16 Dec 2018

In-Text Citation: (Yusoff, 2018)

To Cite this Article: Yusoff, M. (2018). Implementation of Relationship Marketing in Takaful through Wakalah Business Model. International Journal of Academic Research in Business and Social Sciences, 8(11), 98-107.

Copyright: (C) 2018 The Author(s)

Published by Human Resource Management Academic Research Society (www.hrmars.com)

This article is published under the Creative Commons Attribution (CC BY 4.0) license. Anyone may reproduce, distribute, translate and create derivative works of this article (for both commercial and non-commercial purposes), subject to full attribution to the original publication and authors. The full terms of this license may be seen

at: http://creativecommons.org/licences/by/4.0/legalcode

Vol. 8, No. 11, 2018, Pg. 98 - 107

http://hrmars.com/index.php/pages/detail/IJARBSS

JOURNAL HOMEPAGE

Full Terms \& Conditions of access and use can be found at http://hrmars.com/index.php/pages/detail/publication-ethics 


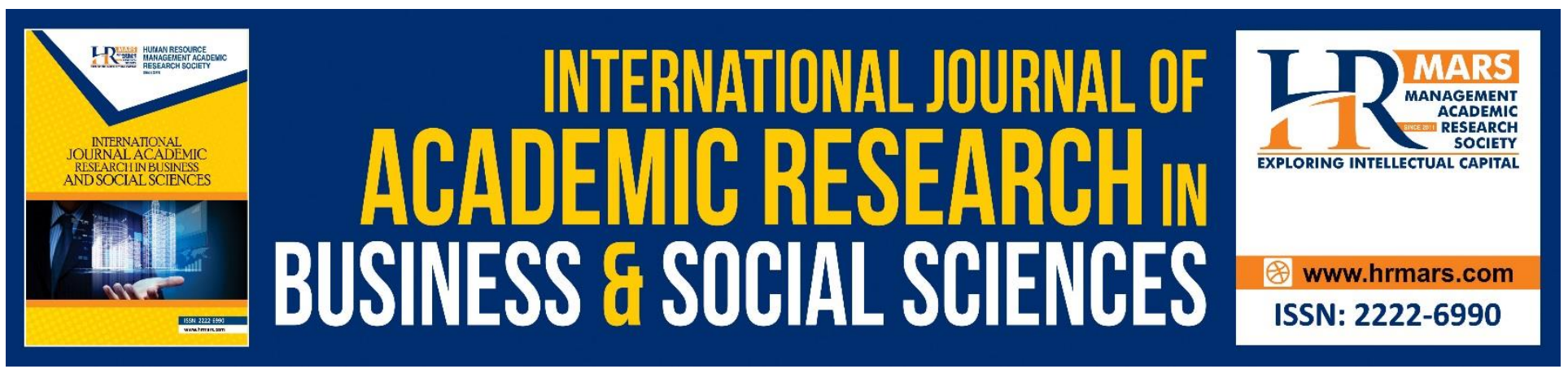

\title{
Implementation of Relationship Marketing in Takaful through Wakalah Business Model
}

\author{
Murni Yusoff \\ Centre for Islamic Development Management Studies (ISDEV), Universiti Sains Malaysia \\ Penang, Malaysia \\ Email: murniyusoff.usm@gmail.com
}

\begin{abstract}
Wakalah is one of the business models in Takaful that is currently applied by all Takaful operators in Malaysia. In Wakalah, the utilization of principal-agent relationships are more than its physical term and conditions in the agency contract. How do principal-agent relationships in Wakalah works in Takaful? How do these relationships connected to marketing of Takaful products and services to public? How does the relationships form a tool of relationship marketing (RM)? Therefore, this paper attempts to achieve two aims. The first aim is to identify the form of RM in Takaful through Wakalah Model. Secondly, to analyze the implementation of RM in Takaful through Wakalah model. The methods used are document research and analyzed with qualitative content analysis. The findings show that there are two forms of RM namely internal RM and external RM that are embedded in the principal-agent relationships of Takaful and can be used as a tool to attract potential prospects and existing customers to participate in Takaful.
\end{abstract}

Keywords: Principal-Agent, Takaful, Wakalah Model, Relationship Marketing

\section{INTRODUCTION}

Takaful is a concept whereby a group of participants mutually guarantee each other against loss or damage occurred. Each participant fulfilled his obligation by contributing a certain amount of donation (Tabarru') into a fund that is managed by the Takaful operator (Bank Negara Malaysia, n.d.).

Currently, Takaful operators in Malaysia have adopted Wakalah business model by operating agency system. Wakalah is defined as Wakalah or Wikalah literally means "preservation". The term Wakalah is also referred to delegation of one's affair to another. The quran verses related to this meaning are described in Surah Ibrahim (14) verse 12 and Surah Hud (11) verse 56 (Wahbah al-Zuhaily, 2007). According to Shafi'is, Wakalah means the delegation of one living person to another of the performance of an act that permits delegation, and that the first person is permitted to perform himself (Wahbah al-Zuhaily, 2007). 
Prior to Wakalah model, Mudarabah model was applied by Takaful operators. However, Takaful operators switched from Mudarabah to Wakalah based on three reasons namely, the ability to receive the Wakalah fees which match the incidence of operational expenses, Wakalah model offers greater flexibility in product pricing in a competitive market, and the applicability of underwriting surplus in Mudarabah that have been the concerns of Shariah scholars. However, there are some companies have combined between Mudarabah and Wakalah and the new hybrid model namely Wakalah-Mudarabah is evolved (Syed Othman Alhabshi, Kamaruddin Sharif, Shaikh Hamzah Abdul Razak \& Ezamshah Ismail, 2012).

In Wakalah model, the utilization of principal-agent relationships are more than its physical term and conditions in the agency contract. How do these relationships connected to the marketing of Takaful products and services? Therefore, this paper attempts to achieve two aims. The first aim is to identify the form of relationship marketing (RM) in Takaful through Wakalah Model. Secondly, to analyze the implementation of RM in Takaful through Wakalah model. The method used is document research and analyzed with qualitative content analysis.

The paper is organized into four main parts. First, the paper describes the application of Wakalah model in Takaful. The second part presents the principal-agent relationship in Takaful. The third part discusses implementation of RM in Takaful while the last part is the conclusion of the paper.

\section{APPLICATION OF WAKALAH MODEL IN TAKAFUL}

The term Wakalah in Arabic gives the meaning of agency. In agency, the structure of relationship is agreed between two parties to conduct a certain business undertaking (Ahmad Mazlan Zulkifli, Badrul Hisham Abdul Rahman, Nasser Yasin, \& Jamil Ramly, 2012).

Wakalah is a delegation of task by the principal to the agent. In the context of Takaful operations, the participants appoint and authorize the Takaful operator to be their agent (wakeel) to manage the Takaful fund that has been principally contributed by the Takaful participants. With this regards, the Takaful participants become the principals in the agency or Wakalah contract (Zaharuddin Abd Rahman, 2014).

In general, agency can be defined as the relationship which arises when the agent is engaged by the principal. Agent in the context of Takaful is called Takaful agent, is a person who does all or any of the activities such as to solicit or obtain proposal or Takaful certificate on behalf of a Takaful operator; to offer or assume to act on behalf of Takaful operator in negotiating a Takaful certificate, or to act on behalf of Takaful operator in relation to the issuance, renewal, or continuance, of a Takaful certificate (IFSA, 2013).

According to Quran, Hadith, and consensus of the scholars, the agency contracts are permissible with proofs. There are number of verses in Quran that have stated the usage of agency and agent in business such as the verses of $18: 19 ; 4: 35 ; 12: 93 ; 12: 55$; and 9:60. The Hadith that mention the 
permissibility of agency are including Sahih al-Bukhari and Muslim. Meanwhile, the consensus of Muslim scholars have permitted the agency contracts with the justification that individuals cannot administer all of their affairs, and thus have to appoint agent with commissions (Wahbah al-Zuhaily, 2007).

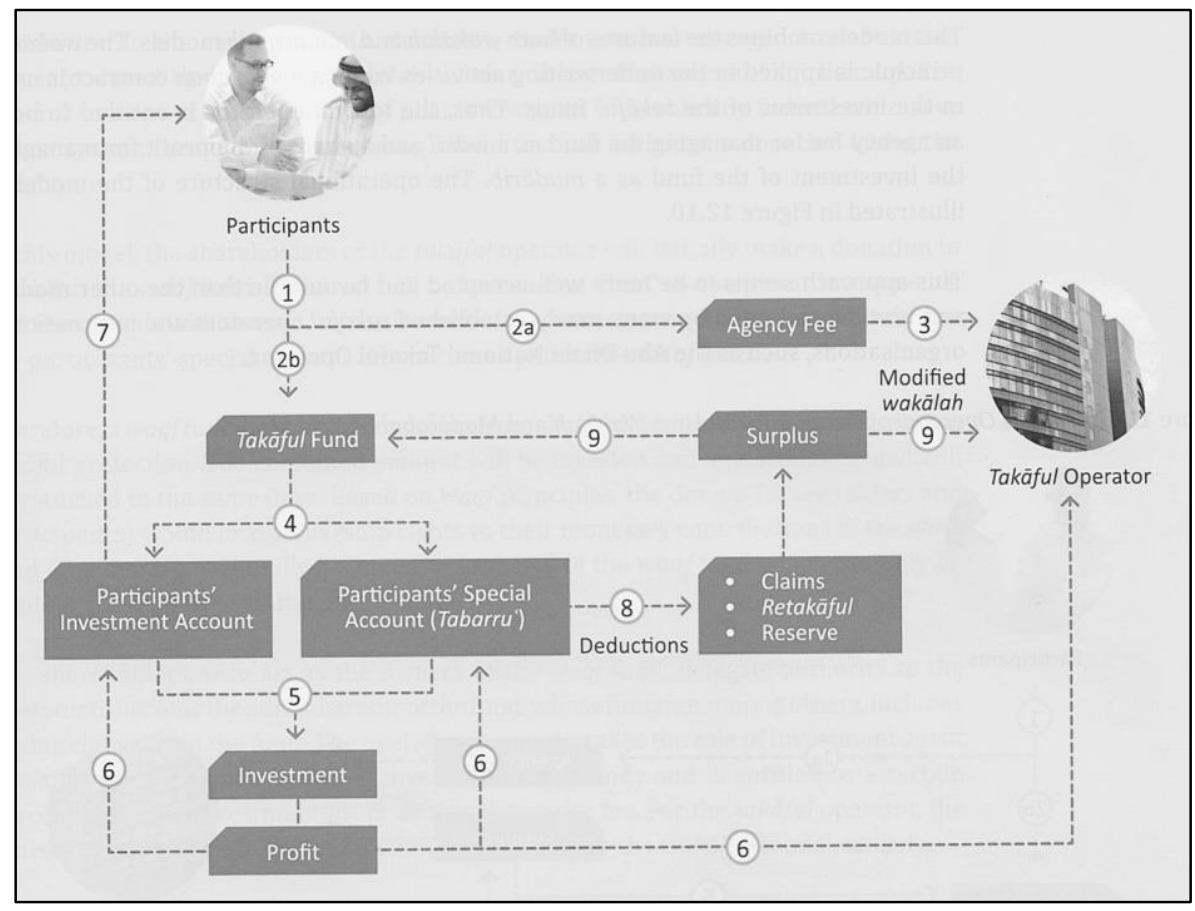

Figure 1: Wakalah Model

Source: Merjan Muhammad \& Mezbah Uddin Ahmed (2016)

According to Figure 1, the participants pay contributions under the Takaful scheme to the Takaful operator. The contributions are divided into agency fee (agent's remuneration and administrative expenses) and Takaful fund (Participant's special account (PSA) and participant's investment account (PIA)). The division is made based on the agree ratio between the Takaful operator and participants in the contract. The fund in both accounts are invested in Shariah compliant assets. If any profit made from the investment, it is added to both accounts and the Takaful operator can be entitled for a performance fee for good performance of the investment. The amount in PIA will be credited to participants when the scheme matured or in the event of death of the insured while the amount in PSA is used to pay claims, Retakaful, and reserve. When there is surplus, it is distributed to the participants at the ened of the year. However, In a modified Wakalah model like current industry practice, the surplus is distributed among the participants and the Takaful operator (Merjan Muhammad \& Mezbah Uddin Ahmed, 2016). 
INTERNATIONAL JOURNAL OF ACADEMIC RESEARCH IN BUSINESS AND SOCIAL SCIENCES

Vol. 8, No. 11, Nov, 2018, E-ISSN: 2222-6990 @ 2018 HRMARS

\section{PRINCIPAL-AGENT RELATIONSHIPS IN TAKAFUL}

Takaful agency system in Malaysia have standardized the application of Wakalah as the business model. There are three relationships identified in Takaful agencies such as relationship between principal and agent, relationship between principal and third party, and the relationship between agent and a third party (Nasser Yassin \& Jamil Ramly, 2011).

Through agency system, each of Takaful operators builds its own agency force by recruiting, financing, training, and supervising the agents. The Takaful agent is legally representing the Takaful operator and has the authority to bind the company in which he represents, subject to certain underwriting authority limit as may be stipulated in the agency contract. The Takaful agent will receive a portion of the contribution as remuneration from Takaful companies for the services rendered. The Takaful agent is subject to the Code of Ethics of Takaful intermediaries in order to ensure the services rendered and ethics observed are of the highest standard. Under this framework, the minimum standards of conduct and the minimum training requirements to be completed by the Takaful intermediaries uphold proper and ethical practices (Bank Negara Malaysia, 2005).

Takaful operators in Malaysia use the agency system for marketing Family Takaful products rather than general Takaful products. The agency system utilized agents who are self-employed and usually restricted to a single Takaful operator. The particular Takaful operator do not allow their agents to market Takaful products especially family Takaful products, for other Takaful operators. The Takaful operators usually compensate these agents by paying attractive commissions. However, some Takaful operators may pay these agents a small basic salary or guaranteed minimum payment especially during an initial training or internship programs. Paying one commission rate on a new business and another, lower rate on renewal business is common in the agency system. Takaful operators in certain countries pay agents as a sliding commission rate where the earlier year commissions are higher than that of the later years (Syed Othman Alhabshi, Kamaruddin Sharif, Shaikh Hamzah Abdul Razak \& Ezamshah Ismail, 2012).

Takaful operators have their own structure of agency system which comprises the flow from top position until the agent. The highest ranking in the structure is the president followed by four key persons that represent the division such as director of agencies, vice president of Takaful operations, vice president of General Takaful operations, and vice president of financial and administration. The Takaful agents are responsible to be managed by the unit managers. Unit managers are supervised by Group Agency Managers while the group agency managers are supervised by Agency development managers and agency development executives. The director of agencies are monitoring all the relationships between Takaful agents with their superiors and also Takaful agents with potential customers or participants. The structure of agency system in Takaful is described in the following Figure 2. 


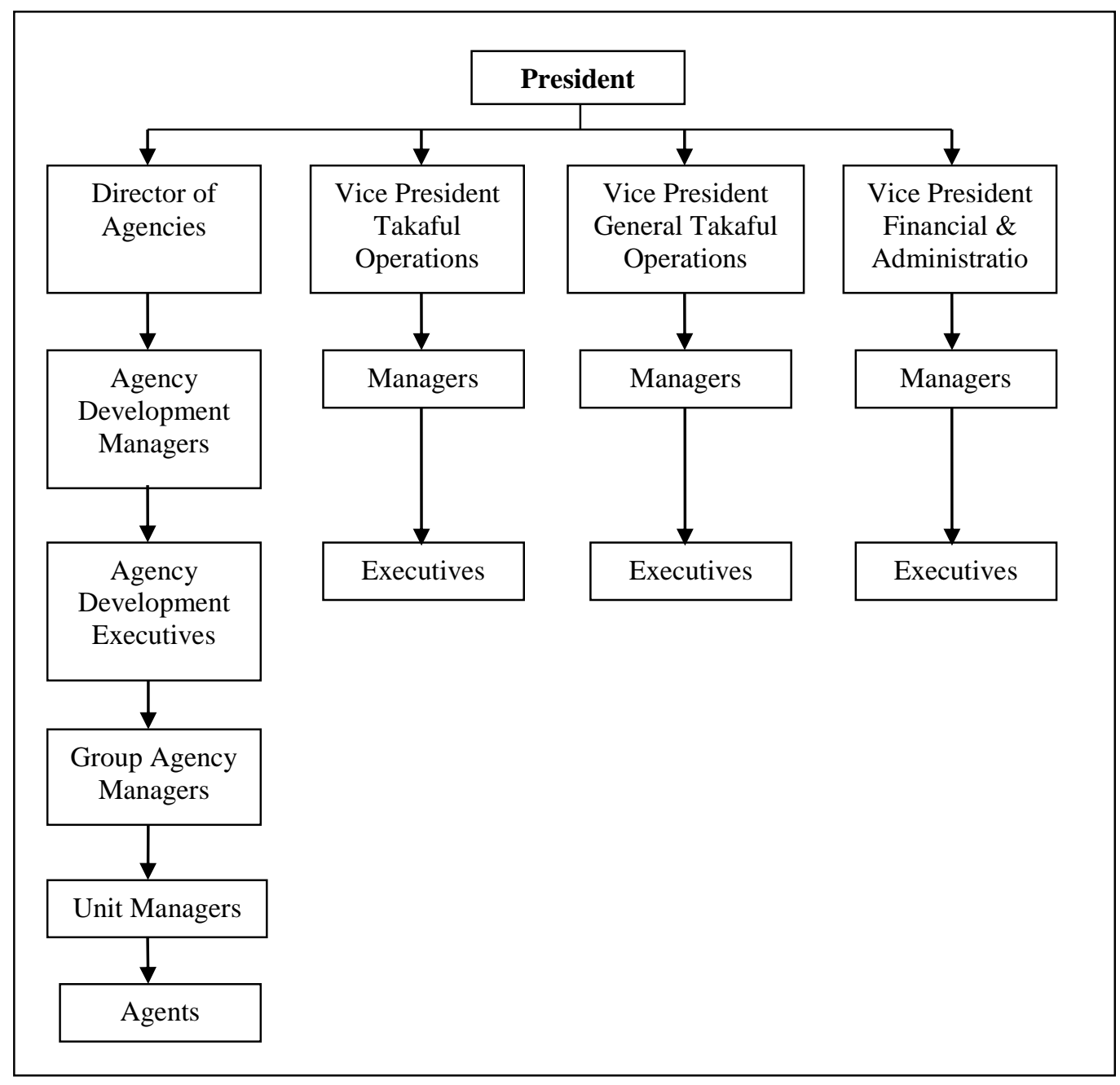

Figure 2: Structure of Agency System in Takaful

Source: Syed Othman Alhabshi, Kamaruddin Sharif, Shaikh Hamzah Abdul

Razak \& Ezamshah Ismail (2012)

Based on the relationships explained through the above structure, it shows that there are not merely the relationships exist in Takaful. In Wakalah contract, a relationship exist in terms of principal-agent between the Takaful operators and the customer who is called Takaful participant. The contract allows the participant to appoint the Takaful operators act as his agent (wakil) to act on his (participant) behalf in administering the Takaful scheme or plan selected and manage the pooledfunds effectively (Nasser Yassin \& Jamil Ramly, 2011). 
In general, Takaful agent has been given authority from the Takaful operators to market the Takaful products and dealing with the participants on behalf of Takaful operators. The agent provides financial relief with assisting the unfortunate participants that having property losses, reducing the burden when the participants die, cultivating discipline to save money among the participants, and spreading the knowledge on the Islamic products to the non-Muslim societies (IBFIM, 2011).

Under Wakalah model, participants remain the actual owners of the Takaful fund and the Takaful operator act as an agent (for the participants) who manage the fund and entitled for agency fee (remuneration) and performance fee (commission). There are two types of Wakalah model such as short-term for general Takaful and long-term scheme for family Takaful. The Takaful fund will be invested and any income or profit will be returned to the group fund.

In a nutshell, there are principal-agent relationships related to marketing described above such as the relationship between Takaful operators with the Takaful agents and another relationship is between the Takaful agents with customers. The next section highlights the forms of RM in Takaful through Wakalah model.

\section{RELATIONSHIP MARKETING IN TAKAFUL}

$\mathrm{RM}$ is widely implemented in various sector including Islamic financial services. RM is one of the approaches in marketing that focuses on customer orientation. RM requires an organization, as a consequence of its business strategy and customer focus, design, and align its business processes, communications, technology, and people in support of the value individual customers want. It is also seeks to develop a chain of relationships within the organization in creating the value customer want and between the organization with its main stakeholders, including suppliers, distribution channels intermediaries, and shareholders (Gordon, 2000).

As discussed earlier, the principal-agent relationships embedded in Wakalah model are required to be nurtured and nourished in Takaful operators to ensure the effectiveness of deliverance of spirit of Takaful. In marketing Takaful products and services, the principal-agent relationships developed are perceived in different way in RM. Both Takaful agent and Takaful operator are perceived as relationship marketers. Both parties have their roles in preserving the relationships as required in Islam and for the purpose of business growth.

In promoting the Takaful products and services to potential prospects and existing customers, the Takaful agent is appointed to represent the Takaful operators in promoting Takaful plans issued and is licensed and registered by Registrar of Takaful Intermediaries namely Malaysian Takaful Association (MTA). There are two types of products in Takaful that can be marketed by agents such as General and Family products. A General Takaful agent can represent a maximum of two General Takaful operators while the Family Takaful agent can only represent a single Takaful operator. Otherwise, the Takaful agent can promote both General and Family Takaful agent by representing one Family Takaful and maximum of two General Takaful operators (Ahmad Mazlan Zulkifli, Badrul Hisham Abd Rahman, Nasser Yassin, \& Jamil Ramly, 2012). 
Based on relationships exist in Takaful, there are two forms of RM identified such as internal RM and external RM. The internal RM represents by relationship between Takaful operators and Takaful agents while the external RM represents by the relationship between Takaful agents with the customers. Both of these forms are implemented in Takaful organization.

Internal RM involves training and motivating employees, and keeping them informed about the company's internal and external strategies, external communication, and market information whereas the relationships promises that are made in External RM had to be facilitated internally and realized in interaction with customers (Liljander, 2000).

In representing internal RM, the roles of Takaful operators are perceived as relationship marketer. In general, there are six roles of Takaful operators are highlighted into priorities. First, the operator needs to sharpen business focus and competitiveness in increasing market share, increasing Takaful penetration, and strengthening the Takaful ecosystem. Second, the operator must ensure wellplanned transition process towards pricing deregulation of motor insurance and Takaful. Third, operator must strengthen operational efficiency and market conduct to attain clear ethical leadership and competitive advantage. Fourth, the operator needs to ensure readiness for effective implementation of domestic regulatory framework and international best practices. Fifth, the operator must secure success through continuous focus in human capital development, while the last priority is to enhance Shariah governance in earning public trust, enhancing awareness and facilitating branding (Syed Moheeb Syed Kamarulzaman, 2012).

Besides, as a principal, Takaful operators provides training programs to Takaful agents and leaders. In general, the training programs provided cover the aspects including Takaful concept and products, basic Takaful course, basic Islamic wealth management, estate planning for Muslim clients, basic Islamic financial planning construction, and Shariah guidelines for agency management (Syed Othman Alhabshi, Kamaruddin Sharif, Shaikh Hamzah Abdul Razak \& Ezamshah Ismail, 2012). Meanwhile, the training programs provided from the Takaful companies are guided by Malaysian Takaful Association (MTA) that covers the topic related to the technical and non-technical subjects such as product knowledge, Takaful operations and customer services, Shariah aspects of Takaful, legal and compliance aspects of Takaful, sales, marketing and after sales services, management skills and development programs, people and management, personal management, general knowledge, and agency development (MTA, n.d.). All of the programs are designed to enhance and enrich the skills to develop and maintain relationships between agents and customers.

Besides training programs, the principal has two major duties to its agents, first, the principal needs to pay remuneration and expenses as agreed. Second, the principal need to indemnify the agent consequences of any act lawfully done, within his authority, on behalf of his principal. In this context, the Takaful companies act as internal relationship marketer (Nasser Yassin and Jamil Ramly, 2011). 
Further, in handling agents, there is code of ethics for agents that have been provided by MTA to all Takaful agents in Malaysia. The code of ethics provided is a standard of ethics and guide for agents in conducting Takaful business. MTA has used the guideline to strengthen universal moral values and consequently to uphold the interests and the welfare of the company, the shareholders, the Takaful participants, the community and the Takaful agents themselves (MTA, n. d.).

On the other hand, external RM also plays important roles in dealing with customers or potential prospects. RM involves two main stages such as customer acquisition and customer retention. For customer acquisition, the organization should have the ability to balance the number of customers being acquired with the number defecting and this requires the determination of the number of customers in each stage of the customer life-cycle and an anticipation of their migration paths. For customer retention, there are two concerns depend on types of product, first, for products with short purchase cycles, the customer continues to purchase the product / service over a specified time period. Second, for products with long purchase cycles, the customer indicates the intention to purchase the product or service at the next purchase occasion (Shajahan, 2004).

In representing external RM, Takaful agent is the relationship marketer that deals with people outside the organization. Takaful agent act as a marketer as well as salesperson in promoting Takaful to people. Based on the training and skills obtained within the organization, they will practice them to the people outside the organization that can be customers, potential prospects, and public. As a relationship marketer, Takaful agent must be more knowledgeable about the customer's requirement and needs. By having knowledge about the customer together with the social rapport built, it facilitates the tailoring or customizing of service according to the customer's specifications (Berry, 2000).

\section{CONCLUSION}

The relationships exists in Takaful based on Wakalah model has been perceived as one of the tools in RM besides having good and competitive products and services in the market. Although the RM introduced by Western in literatures and application are more prominent and popular, yet, the missing dimension in their model and application is from the dimension of religious adherence. Moreover, the root of the existing RM is based on Western ethno-centric and totally different with Islamic In Islam, they are different concept of relationships from the Western and other culture and religions. Thus, the religious adherence is the symbol of belief of Tawheed in Islam. Tawheed acts as the core in Islamic worldview whereby the three relationships exist in representing the connection with Allah SWT and man. Those relationships are relationship between man and Allah SWT, relationship among man, and relationship between man and universe. Hence, the future research is needed to identify the appropriate RM approach that comply with needs of Muslim businesses from the Islamic philosophical underpinnings. 
INTERNATIONAL JOURNAL OF ACADEMIC RESEARCH IN BUSINESS AND SOCIAL SCIENCES

Vol. 8, No. 11, Nov, 2018, E-ISSN: 2222-6990 @ 2018 HRMARS

\section{REFERENCES}

Zulkifli, A. M., Rahman, B. H. A., Yassin, N. \& Ramly, J. (2012). Basic Takaful practices: entry levels for practitioners. Kuala Lumpur: IBFIM.

Bank Negara Malaysia. (2005). Concepts and Operations of General Takaful Business in Malaysia. Retrieved from http://www.bnm.gov.my/files/ publication/tkf/en/2005/booklet.en.pdf

Bank Negara Malaysia. (n.d.). Islamic Banking \& Takaful. Retrieved fromhttp://www.bnm.gov.my/index.php?ch=fs_mfs \&pg=fs_mfs_bank

Berry, L.L. (2000). Relationship marketing of services: growing interest, emerging perspectives. In Handbook of relationship marketing. Sheth, J.N. \& Parvatiyar, A. (Eds.) Sage Publications, Inc: Thousand Oaks.

IBFIM. (2011). Buku Panduan Asas Takaful. Kuala Lumpur: Institute of Islamic Finance and Banking Malaysia (IBFIM).

IFSA. (2013). Islamic Financial Services Act. Retrieved from http://www.bnm.gov.my /documents/act/en_ifsa.pdf

Gordon, I. (2000). Organizing for relationship marketing. In Handbook of relationship marketing. Sheth, J.N. \& Parvatiyar, A. (Eds.) Sage Publications, Inc: Thousand Oaks.

Merjan Muhammad \& Mezbah Uddin Ahmed. (Eds.). (2016). Islamic financial system: principles and operations. $2^{\text {nd }}$ ed. International Shari' ah Research Academy for Islamic Finance (ISRA): Kuala Lumpur.

MTA. (n.d.). Guidelines on the Continuing Professional Development (CPD) Hours. Retrieved from http://www.malaysiantakaful.com.my/mta.optima.my /files/25/ 25450264-d93e-4240b602-669ae1a38ef1.pdf

Yassin, N. \& Ramly. J. (2011). Takaful: A study guide. Kuala Lumpur: IBFIM.

Shajahan, S. (2004). Relationship marketing: Text and cases. New Delhi: Tata McGraw-Hill Publishing Company Limited.

Kamarulzaman, S. M. S. (2012). Critical issues facing Takaful operators. Retrieved from http://www.Takaful.coop/images/stories/1.1.1\%20SMoheeb\% 20Critical20lssues\%20Facing\%20Malaysian\%20Takafu/200perators.pdf

Alhabshi, S. O., Sharif, K., Razak, S. H. A. \& Ismail, E. (2012). Takaful: Realities \& challenges. Petaling Jaya: Pearson Malaysia.

Wahbah al-Zuhayli. (2007). Financial transactions in Islamic jurisprudence Volume 1. 2nd Ed. Damascus: Dar al Fikr.

Rahman, Z.A. (2014). Contemporary Islamic finance architecture. IBFIM: Kuala Lumpur. 